\title{
The Development of Indonesian Language Teaching Materials for Beginner Level of Foreign Speakers with Local Content
}

\author{
Suwandy Tanwin ${ }^{1}$, Rosliani ${ }^{2}$ \\ ${ }^{1}$ Postgraduate Indonesian Language and Literature Education, Universitas Prima Indonesia \\ ${ }^{2}$ Balai Bahasa Sumatera Utara, Indonesia \\ suwandytan83@gmail.com; rosliani.12@gmail.com
}

\begin{abstract}
This research is motivated by the scarcity of Bahan Ajar Bahasa Indonesia Untuk Penutur Asing (BIPA), especially cultural-charged teaching materials. Therefore, the development of BIPA teaching materials is needed. The problems examined in this study are (1) how the process of developing BIPA teaching materials containing Batak culture for beginner-level foreign speakers, (2) how the final results of the development of BIPA-charged Batak culture materials for beginner-level foreign speakers, (3) how the materials are feasible BIPA teaching contains Batak culture for beginner-level foreign speakers. This research uses the Research and Development $(R \& D)$ approach which is carried out in five stages, namely: (1) preliminary survey, (2) initial prototype development, (3) product design, (4) product validation, (5) product revision and improvement. This study uses two data collection techniques, namely observation and interviews to obtain data on the needs of teaching material development and assessment of teaching material prototypes. The results of this study are as follows. First, the development of BIPA teaching materials with Batak culture for beginner-level foreign speakers is carried out in five stages, namely: (1) a preliminary survey with techniques for analyzing existing teaching materials, (2) initial prototype development, (3) product design, (4) product validation, and (5) product revision and improvement. Second, the prototype of teaching material is developed with three parts including (a) physical form, (b) book cover, (c) content / material content. Third, the evaluation from experts which includes the graphic aspect gets $89.29 \%$. In the aspect of content/material obtained $78.57 \%$. In the presentation aspect, it gets $83.33 \%$. Aspects of language and readability, obtain $100.00 \%$.
\end{abstract}

Keywords

Indonesian teaching materials for foreign speakers (BPA); Batak culture; beginner-level

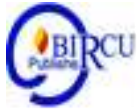

\section{Introduction}

The Indonesian language currently plays an important role in its position in the language of the international community. The regional government of Ho Chi Minh City, Vietnam, has placed Indonesian as the second foreign language since December 2007. Indonesian is also spoken in Malay-speaking countries, such as Malaysia, Singapore, Brunei Darussalam, and communities on other continents. Andayani (2015: 401) argued that in one of the presentations at the plenary session of the IX Indonesian Language Congress, the application stated that currently there are 45 countries that teach Indonesian, such as Australia, America, Canada, Vietnam, and many other countries. For example, in Australia Indonesian is the fourth popular language.

This development is inseparable from the government's efforts through the Ministry of Education and Culture (Kemendikbud) Biro Perencanaan Kerja Sama Luar Negeri (BPKLN), which provides scholarships to foreign students to study languages and culture 
in Indonesia. The program is named Darmasiswa. Darmasiswa is a scholarship program that is offered to students from countries that have diplomatic relations with Indonesia to study Indonesian, arts, music and crafts. The main objective of the Darmasiswa main program is to increase interest in Indonesian language and culture among youth from other countries. This is also expected to form a strong cultural network to foster understanding between participating countries.

Bahasa Indonesia Untuk Penutur Asing (BIPA) likened to "shoots" that has just grown and needs to be developed carefully so that it can produce solid and beneficial results for all groups. Therefore, to ensure that BIPA can be developed professionally and systematically, a careful study and arrangement of BIPA learning is required by paying attention to all elements, from institutional management, teaching staff, teaching systems, teaching materials, media, and other related matters with BIPA learning.

In its development, the Indonesian language has now contributed significantly to the Indonesian nation. This can be seen from the increasing number of other nations interested in learning Indonesian. Based on data from the Ministry of Foreign Affairs in 2012, Indonesian has the fifth largest native speaker in the world, with 4,463,950 people spread abroad. In fact, the Chairman of the Indonesian Parliament in the 32nd ASEAN Inter Parliamentary Assembly (AIPA) session in 2011 suggested Indonesian as one of the working languages in the AIPA sessions. It is not only that, according to the Head of the Language Development and Development Agency, Ministry of Education and Culture, Mahsun, he said that currently at least 45 countries are participating in BIPA, with 174 places for BIPA implementation spread across various countries and the most in Australia (www. education.kompas.com).

However, these developments have not been accompanied by adequate instruments to support these BIPA learning activities. One of the obstacles that is still being faced is the availability of teaching materials. There are not many teaching materials available for BIPA learning in Indonesia. Currently, BIPA organizers still use various books according to the characteristics of their students. For institutions that have not published their own BIPA book, they use the Badan Bahasa midwife. Before 2015, the books distributed by the Language Agency were the Lentera 1 book for basic BIPA students, Lentera 2 for intermediate BIPA students, and Lentera 3 for advanced BIPA students. However, in 2015, the Language Agency launched the book Sahabatku Indonesia in six volumes. The book has met six competency levels for BIPA students (A1-A2 for beginner BIPA students; B1-B2 for intermediate BIPA students, and C1-C2 for advanced BIPA students). The book is compiled based on a curriculum based on the Common European Framework of Reference for Languages produced by a curriculum workshop in Yogyakarta in 2014. Apart from being in print, the book can be downloaded from the Indonesian Language Agency website.

In addition, at this time there is still no agreement on how to teach Indonesian to foreign speakers effectively, both with regard to the means to achieve goals, the material that should be taught, and the teaching methods (Wojowasito, in Azizah, et al. 2012). Practices that occur in the field are found in various BIPA learning strategies. This shows that teaching Indonesian as a foreign language is not easy and requires many components, one of which is by including cultural elements in BIPA learning.

Culture is one of the supporting aspects of BIPA learning. Cultural aspects have a very important role in meeting the targets of BIPA learning. The purpose of including cultural aspects in BIPA learning is to instill cultural awareness in foreign speakers in learning Indonesian so that foreign speakers can easily communicate in Indonesian cultural situations.

Foreign speakers who learn cultural aspects can take advantage of these cultural insights as a provision for their life in Indonesia. The cultural aspect supports foreign speakers in speaking Indonesian according to the situation and condition of Indonesian 
society. In addition, introducing Indonesian culture to foreign speakers can also foster a positive and appreciative attitude for foreign speakers towards the richness of Indonesian culture.

Judging by the importance of linking Indonesian culture in BIPA learning, including Batak culture in BIPA teaching materials is considered an appropriate effort, considering that there are quite a lot of foreign speakers working in North Sumatra. This is in line with data from the Central Statistics Agency of North Sumatra Province, which recorded 279 foreign speakers working in North Sumatra in 2015 (https://sumut.bps.go.id/).

Based on the identification of these problems, research and development of Indonesian language teaching materials containing Batak culture for beginner-level foreign speakers were carried out. The purpose of this research and development is to produce Indonesian language teaching materials for foreign speakers (BIPA) specifically for beginner level learners covering four aspects of language skills (reading, writing, listening, and speaking) with Batak cultural content. This research and development is also expected to provide benefits, namely (1) providing good and detailed information about the development of BIPA teaching materials with local culture, (2) helping the achievement of the main objectives of the Darmasiswa program, namely promoting and increasing interest in Indonesian language and culture among youth. from other countries, (3) as learning materials in an effort to improve Indonesian language skills and gain insight into Indonesian culture, especially Batak culture, (4) add teaching materials, especially BIPA teaching materials containing Batak culture for beginner-level foreign speakers, and (5) learning materials or subsequent research references.

\section{Research Methods}

This research model refers to the research and development design (Research and Development) of Borg and Gall which has been modified by Sugiyono (2010). Contextually, according to Borg and Gall, educational development research is a research method that aims to improve the quality and quality of education through the products produced.

Furthermore, Borg and Gall describe four main characteristics in research and development, namely:

1. Conducting preliminary studies or research to find research findings related to the product to be developed,

2. Developing products based on the research findings,

3. Conducting field tests in real settings or situations where the product will be used later, and

4. Revising by fixing the weaknesses found.

Based on the definition and four main characteristics, Borg and Gall also describe the steps taken in conducting development research as shown in the following diagram.

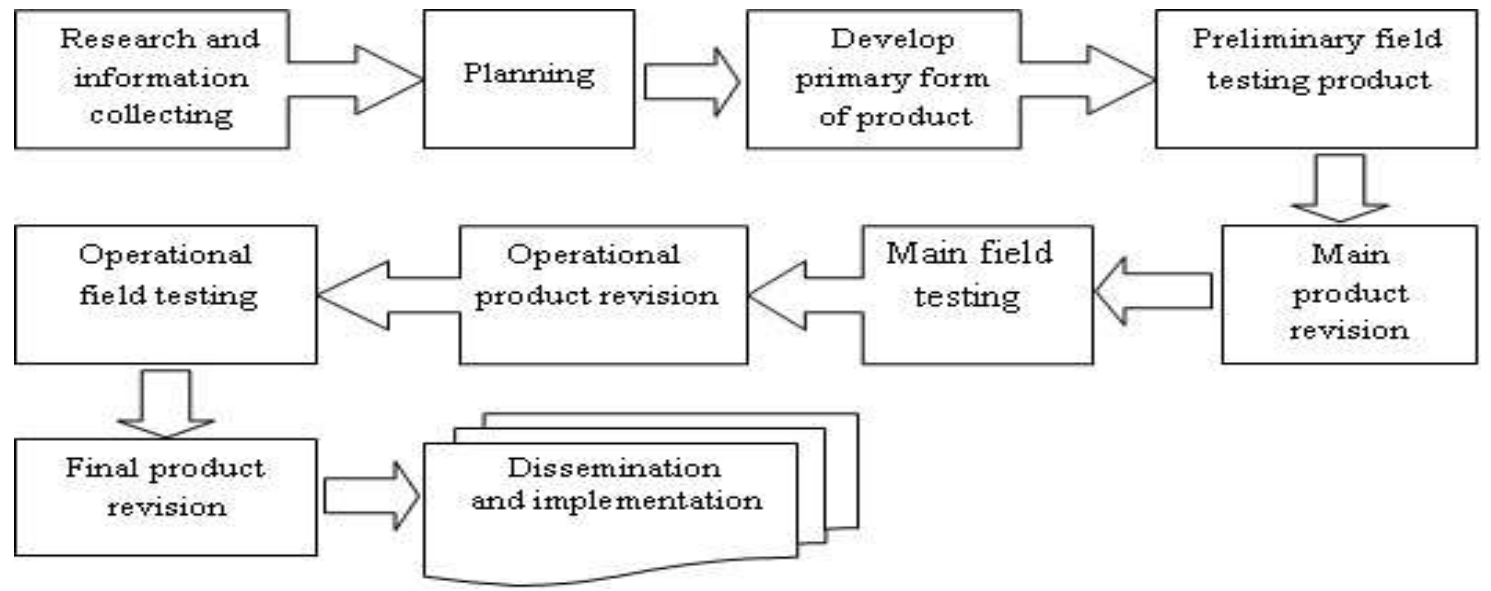

Figure 1. Borg and Gall's Research and Development Model 
In line with the teaching materials development process, adjustments were made by limiting the research to five stages, namely the revision / design improvement stage after design validation by experts. The research is only carried out on a limited scale, both a needs questionnaire and a validation test so that researchers make reductions without intending to reduce the quality of Research and Development (R\&D). The scope of this research is the development of BIPA teaching materials with Batak culture for beginner-level foreign speakers. The five stages referred to in this study are as follows :

1. Step 1, preliminary survey to formulate potentials and problems. This stage includes the activity of finding relevant literature sources and research results as well as conducting literary studies.

2. Step 2, the initial development of a prototype before developing a teaching material design includes the following activities: (a) analyzing the needs of foreign speakers and BIPA teachers for the development of BIPA teaching materials with Javanese culture for entry-level foreign speakers through questionnaires, and (b) compiling material designs.

3. Step 3, product design, which is the activity of designing BIPA teaching materials with Javanese culture for beginner-level foreign speakers which includes activities (a) compiling a draft topic, (b) compiling book text, (c) adjusting book content to the needs of foreign speakers and BIPA teachers, and (d) finalizing the draft book.

4. Step 4, product validation, is an assessment of the quality of the product that has been designed which includes assessment activities by experts to assess the prototype of BIPA teaching materials with Javanese culture for entry-level foreign speakers.

5. Step 5, product revision and repair, is the process of re-correcting and correcting mistakes after validating the product.

After the fifth stage was completed, a description of the results of the study was carried out to describe the BIPA teaching materials containing Batak culture for foreign speakers of the beginner level developed by the researcher. The research design is visualized in the following diagram.

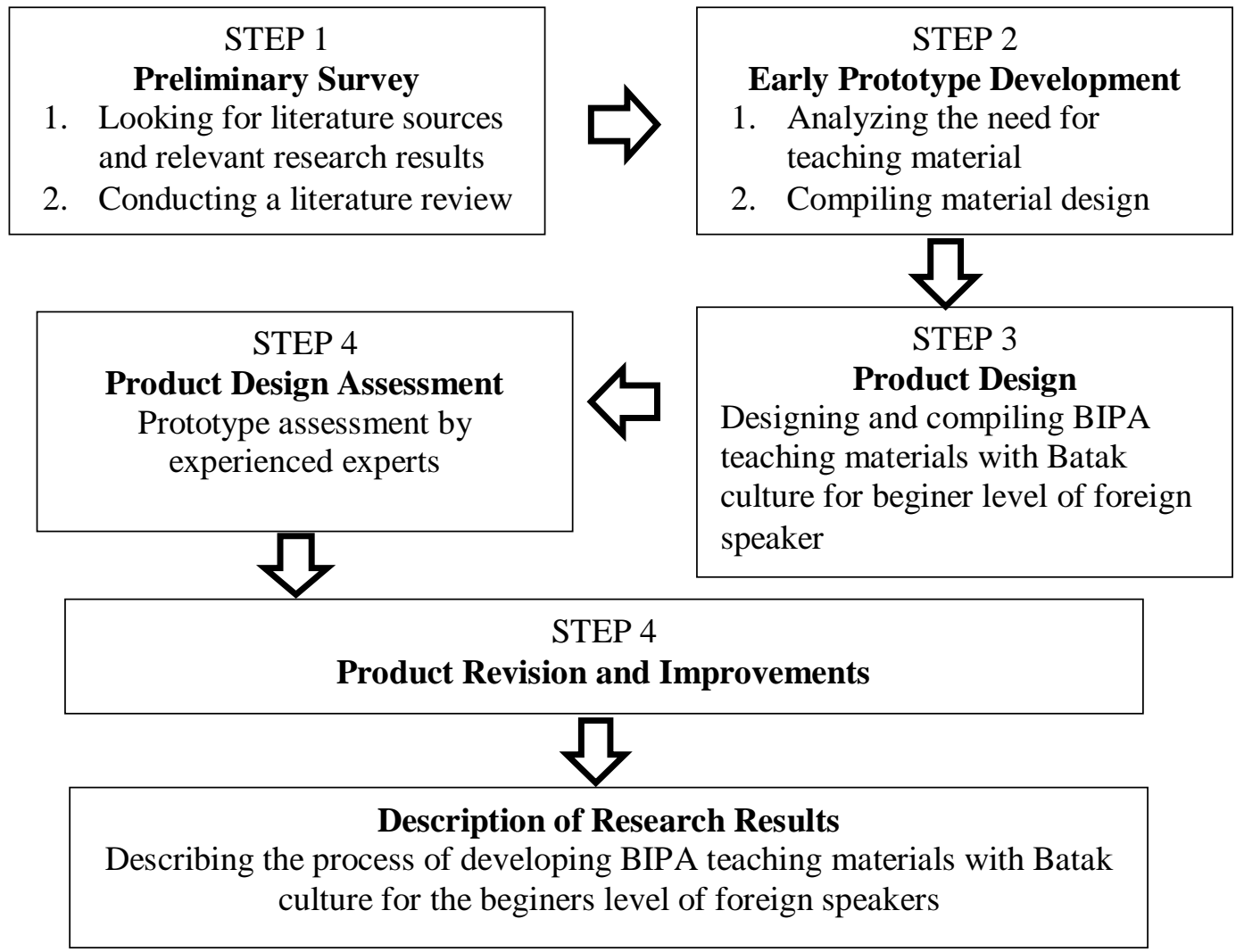

Figure 2. The Stages of Research on the Development of BIPA Teaching Materials 
This study uses two categories of research data sources. First, the data source for the analysis of Indonesian language teaching materials for entry-level foreign speakers. Data for the purposes of analyzing Indonesian language teaching materials for foreign speakers at the entry level used are Indonesian language teaching materials for foreign speakers entitled "Sahabatku Indonesia" Level A1 issued by the Center for Strategy Development and Linguistic Diplomacy, Language Development and Development Agency, Ministry of Education and Culture, in 2016. Second, product validation data sources that will assess the prototype of Indonesian language teaching materials containing local Batak culture for entry-level foreign speakers. The source of product validation data from the development of BIPA teaching materials with Batak culture for beginnerlevel foreign speakers consists of material experts and teaching material designs. Material experts and teaching material designs who act as validators of teaching material products in the form of BIPA books developed in this study, namely Yolferi, S.S., M.Hum.

The variables in this study are the independent variables and the dependent variable. The dependent variable in this study is BIPA teaching materials containing Batak culture for beginnerlevel foreign speakers. Furthermore, the independent variable is the response and attitude towards BIPA teaching materials containing Batak culture for beginner-level foreign speakers.

The second instrument for data collection is the validation test of the BIPA teaching material prototype in the form of an evaluation sheet for BIPA teaching materials. The instrument is focused on evaluating the prototype of teaching materials and their relevance to support learning. The results of the expert's assessment are then used as a reference for improving the resulting teaching material prototype. The prototype validation instrument for BIPA teaching materials containing Batak culture was developed based on the format of the teaching material evaluation instrument (Depdiknas 2008). There are four aspects in this instrument which include (1) composing and graphic aspects of BIPA teaching materials, (2) content / material aspects of BIPA teaching materials, (3) aspects of the presentation of BIPA teaching materials, and (4) linguistic aspects of BIPA teaching materials. An overview of the research validation guideline sheet can be seen in the following table.

Table 1. Indicator of Prototype Validation of BIPA Teaching Materials

\begin{tabular}{|c|c|c|c|}
\hline No & Aspects & Indicator & Number \\
\hline \multirow[t]{6}{*}{1} & \multirow{6}{*}{$\begin{array}{l}\text { Changes } \\
\text { and } \\
\text { Graphics }\end{array}$} & Color composition & 1 \\
\hline & & Cover image display & 2 \\
\hline & & Writing on the cover & 3 \\
\hline & & Use of fonts; type and size & 4,5 \\
\hline & & Layout & 6 \\
\hline & & Illustrations, pictures, photos & 7 \\
\hline \multirow[t]{5}{*}{2} & \multirow{5}{*}{$\begin{array}{l}\text { Content / } \\
\text { Material }\end{array}$} & Compliance with the BIPA A1 syllabus & 8,9 \\
\hline & & Conformity with the needs of foreign speakers & 10 \\
\hline & & In accordance with the set time & 11 \\
\hline & & The truth of the substance of the learning material & 12 \\
\hline & & Cultural content & 13,14 \\
\hline \multirow[t]{3}{*}{3} & \multirow{3}{*}{$\begin{array}{l}\text { Presentation of } \\
\text { material }\end{array}$} & Order of serving & $15,16,17$ \\
\hline & & Giving motivation, attraction & 18,19 \\
\hline & & Completeness of information & 20 \\
\hline \multirow[t]{3}{*}{4} & \multirow[t]{3}{*}{ Language } & $\begin{array}{l}\text { Compliance with Indonesian language rules } \\
\text { good and true }\end{array}$ & 21 \\
\hline & & Legibility & 22 \\
\hline & & Language is clear and easy to understand & 23 \\
\hline
\end{tabular}




\begin{tabular}{|l|l|c|}
\cline { 2 - 3 } & $\begin{array}{l}\text { Utilization of language effectively and efficiently } \\
\text { (clear and concise) }\end{array}$ & 24 \\
\cline { 2 - 3 } & The rules of politeness in language & 25 \\
\hline
\end{tabular}

To collect data, used data collection techniques with observation and questionnaires. Observations were made by observing existing teaching materials. Meanwhile, the data collection technique with a questionnaire was used during the prototype validation test. The form of validation test questionnaire questions addressed to the expert is an open question with scoring.

The data analysis technique used is descriptive statistics. Descriptive statistics are statistics used to analyze data by describing or describing the collected data as is from the sample (Sugiyono 2010: 208). Qualitative data obtained from observations and collected questionnaires, then grouped by variables and types of respondents. Next, tabulate the data and perform calculations to draw conclusions. After that, draw conclusions from the data exposure in the form of prominent findings and expert corrections so that they are able to meet the research objectives.

\section{Discussion}

\subsection{Teaching Materials Development Process}

The process of developing teaching materials includes activities to find relevant library sources and research results as well as conducting literary studies. The results of the analysis of Indonesian language teaching materials for foreign speakers entitled "Sahabatku Indonesia" Level A1 issued by the Center for Strategy Development and Language Diplomacy, Language Development and Development Agency, Ministry of Education and Culture, in 2016 are as follows:

1. The composition of the graphics and colors contained in the teaching materials has colorful abstract nuances and does not describe any characteristic of Indonesian culture.

2. The cover appearance does not describe Indonesia as having a variety of cultures.

3. There are no illustrations, pictures, and photos in the teaching materials that have cultural nuances in Indonesia.

4. The lack of cultural content in teaching materials.

5. The name of the person, area, floor plan or location contained in the teaching materials still shows the dominance of Java Island (Java centric).

With reference to the results of the analysis of teaching materials, researchers developed BIPA teaching materials with Batak culture for beginner-level foreign speakers. The teaching material is entitled Indonesian Language for Foreign Speakers: Variety of Indonesian Sahabatku Level A1.

\subsection{Product Description}

The product developed is an intermediate level BIPA teaching material with references to the American Council on the Teaching of Foreign Language (ACTFL), an integrative and communicative learning model. The product is named Indonesian Language for Foreign Speakers: Ragam Sahabatku Indonesia. This teaching material is equipped with a teaching guide and a listening CD to practice listening activities.

Teaching materials are designed for 12 units which contain different and functional topics so that BIPA students can directly practice them in their daily lives. Each unit has an integrated learning section between listening, speaking, reading, writing, and grammar.

The titles of the units were made communicative, the titles were (1) How are you, Ucok ?, (2) Introduce, I am Baskara, (3) The Togar family, (4) Happy birthday, Marisi, (5) Go on a trip to Berastagi, (6) Momo, Patar's cute cat, (7) Let's go to the museum! (8) Patar's activity, (9) Opung 
Patar's house, (10) Come on, sing together!

The principles for developing BIPA teaching materials with Batak culture for foreign speakers at entry level are based on the results of the analysis as follows.

\section{a. Material or Content Rules}

The material / content of BIPA teaching materials containing Batak culture for entry-level foreign speakers is based on the principles of relevance, adequacy, adaptive, and innovative. The principle of relevance means that the material in teaching materials is in accordance with the predetermined beginner-level BIPA syllabus. The content of the core material needed according to the perceptions of BIPA teachers and foreign speakers includes (1) dialogue and reading, (2) enrichment, and (3) grammar. Syahrin (2018) stated that the study of language and culture in general is focused on ideas, conceptions and beliefs that humans have, but not to cover everything that people do. Because not everything that people do can have an interesting relationship with language.

Apart from the principle of relevance, the development of material in teaching materials also pays attention to the principle of sufficiency. This means that the material presented is able to guide foreign speakers to master predetermined competencies. The material is neither too much nor too little. The material is given proportionally with due observance of BIPA competence and the allocation of learning time provided. The principle of sufficiency is manifested by presenting examples and easy material descriptions to support the understanding of beginner-level foreign speakers.

BIPA material development also pays attention to the adaptive principle. Adaptive to the level of knowledge and background of foreign speakers. The material is prepared with an easy difficulty level for beginner-level foreign speaker characters in North Sumatra, especially Medan City. The Batak cultural background is also the main focus of the development of this teaching material. Foreign speakers have very low knowledge of Batak culture, so the content of the material is adapted to the light Batak culture and is still developing in North Sumatra. This aims to make it easier for foreign speakers to observe and learn things that are part of the daily life of foreign speakers while in North Sumatra.

\section{b. Presentation of Material}

Presentation of material uses self-instructional and systematic principles. The purpose of the self-instructional principle is that teaching materials developed by foreign speakers can teach themselves without having to rely entirely on BIPA teachers. Systematic principles relate to the organization and presentation of instructional materials in sequence, ranging from material with a low level of difficulty to difficult ones, ranging from concrete material to abstract material. The order of the material adjusts to the respondent's need for teaching materials. The order of the materials in the teaching materials begins with dialogue and reading, continues with enrichment, and ends with grammar material.

\section{c. Language and Grammar}

The language and legibility aspects use the principles of adaptive, consistency, and relevance. The adaptive principle is applied in the use of language and the choice of words according to the level of ability of foreign speakers. As the results of the needs analysis, the choice of words needed is a choice of words that are easy to understand and do not contain scientific terms. The adaptive principle is also used in the variety of languages used. The variety of languages needed by foreign speakers and BIPA teachers is the official language variety but not too standard, adjusting to the description of the needs of the material. 
The principle of consistency is applied to the presentation of linguistic elements and layout in the form of spacing between sentences and the use of various languages. The principle of consistency is useful for supporting the level of readability and understanding of foreign speakers of the material presented. In line with the principle of consistency, the principle of relevance is used in the choice of language types and the use of words / diction. The variety of language and words / diction used is adjusted to the level of ability and knowledge of beginner foreign speakers.

\section{d. Graphics}

The principles of consistency and relevance are also applied to graphic aspects. In accordance with the results of the needs analysis, BIPA teaching materials are equipped with illustrations that are in accordance with the content and description of the material in the teaching materials. The coloring on the cover pays attention to the principle of relevance to Batak culture. The covers are arranged in a festive look with colors that match the characteristics of Batak culture. Teaching materials are arranged in A4 size. The principle of consistency is also the basis for the development of teaching materials, especially in the use of fonts, font sizes, and color selection. The development of BIPA teaching materials containing Batak culture using Arial letters, size 11 pt. The orientation of the book is vertical (portrait). The color choices have the same character, starting from the skin to the content.

The prototype of teaching materials being developed is categorized into five parts, including: physical form, book cover, content / material content, and attachment of complementary material.

1. Physical From

Teaching materials are prepared using white 80 gram HVS paper measuring A4 (210 x 297 $\mathrm{mm})$. The book cover uses a soft cover. Teaching materials are arranged in 60 pages thick according to material needs.

2. Book Cover

The cover is designed according to the analysis of teaching materials in the graphic aspects and characteristics of Batak culture. The cover is designed with a colorful and attractive composition of colors, images and writing. The color variants chosen were the colors and photos characterized by the Batak culture. The selection of the front cover photo is adjusted to the theme of the teaching material being developed, namely Batak culture. Meanwhile, the writing used for writing the title on the book cover consists of two types of writing, namely for large titles using the Arial Black font with a font size of 31 and for small titles using the Pristina typeface with a letter size of 32. The following is a cover prototype of teaching materials with Batak culture.

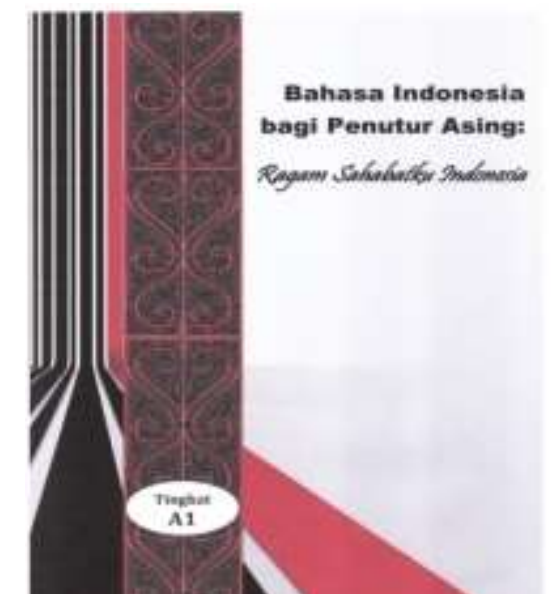

Figure 3. BIPA Teaching Material Prototype Cover 


\section{List of Content / Material}

The completeness of the content of the teaching material consists of three parts, including: (a) introduction, (b) content, and (c) closing. The introductory page consists of the cover page in the book, the foreword, the table of contents, and the mapping. The cover page section in the book contains the book title, illustrations, and target book users.

The next part of the introduction is the table of contents. This section contains a list of all materials along with pages to make it easier to quickly search for subjects. Furthermore, the competency mapping section contains learning objectives based on competence.

The contents of BIPA teaching materials can be described as follows:

a) Introduction

This section contains the titles / themes for foreign speakers to learn. The information presented includes chapter titles that conform to the BIPA syllabus. This introductory page is also accompanied by a picture that aims to provoke curiosity and motivate foreign speakers to study the material in each chapter. Here is one of the introductory page views.

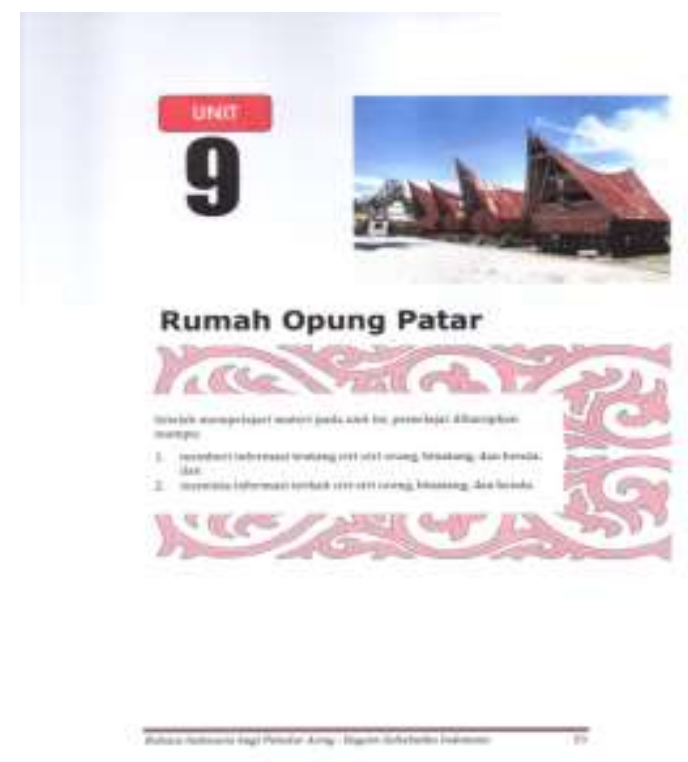

Figure 4. Introduction to the Prototype Chapter of BIPA Teaching Materials

\section{b) Core Material}

In accordance with the needs of foreign speakers and BIPA teachers, the content of the core material in teaching materials is grouped into three parts in the order of (1) dialogue and reading, (2) enrichment, (3) grammar. Apart from the three core materials, this section is also integrated with the practice section on the four aspects of language. The determination and detailing of this material is based on the competencies that must be mastered by foreign speakers. The order of the presentation of the material content has also been adjusted to the needs of the respondent, as well as the stages of attaining competence and the level of difficulty of the material. The content of Javanese culture is presented in the cultural insight section and is integrated into dialogue and reading in each chapter. The entire teaching material is equipped with illustrations that are useful to support the understanding of foreign speakers. The understanding of the core material for each chapter is as follows :

1) Dialogue and Reading

The dialogue presented is a conversation that prioritizes everyday topics about real language events that are needed and can be applied by foreign speakers in daily communication. The learning material in the form of dialogue is very useful for enhancing 
and enriching the vocabulary mastery of foreign speakers, as well as being useful for introducing language structures that are acceptable for everyday language use. The material for this conversation starts with a very simple dialogue, for example dialogue about introductions, asking for news, and so on. This section is also integrated with Batak culture.

Apart from the dialogue section, this section also presents the reading. The reading in this BIPA teaching material aims to foster the confidence of foreign speakers that foreign speakers are able to read Indonesian texts. Reading also aims to encourage foreign speakers to stay enthusiastic in learning Indonesian. The reading presentation is selected according to the ability of a beginner-level foreign speaker. The material is neither too easy nor too difficult. Reading material that is too easy can make foreign speakers bored because they gain little learning experience from their learning activities. Conversely, reading material that is too difficult can make foreign speakers lose their enthusiasm for learning because foreign speakers are frustrated by not being able to understand the text they are reading. Reading materials are material that the researcher develops himself and is also developed from existing reading materials. The material is chosen with the latest topics in order to attract foreign speakers.

2) Vocabulary

The second part of the material is presented with the vocabulary according to the theme in each chapter. This vocabulary section is presented as an effort to enrich the material in each chapter. The vocabulary that is presented adapts to the vocabulary used in everyday life. The vocabulary material also aims to make it easier for foreign speakers to learn Indonesian as a whole without separate words for words. Foreign speakers can also use this vocabulary in real life in society.

3) Grammar

In this section, material on standard Indonesian grammar is presented. The Indonesian grammar that is presented is basic Indonesian grammar, such as pronouns, use of affixes, use of pronouns, and so on. Grammar becomes absolute material in BIPA teaching materials. This is because at the initial level, foreign speakers will be exposed to a new sentence structure. This means that foreign speakers must adapt to the Indonesian sentence structure. The more differences in the sentence structure system between the original language and Indonesian, the more difficulties will be encountered by foreign speakers.

4) Aspect of Indonesian Language

To deepen the material given, the ability of foreign speakers is trained with language skills that are adapted to the material. The four aspects of Indonesian language, namely listening, speaking, reading, and writing. The four aspects of language skills are presented together with the core material.

\subsection{Product Validation Results}

The prototype validation instrument for BIPA teaching materials containing Batak culture was developed based on the format of the teaching material evaluation instrument (Depdiknas 2008). There are four aspects in this instrument which include (1) composing and graphic aspects of BIPA teaching materials, (2) content / material aspects of BIPA teaching materials, (3) aspects of the presentation of BIPA teaching materials, and (4) linguistic aspects of BIPA teaching materials. An overview of the research validation guideline sheet can be seen in the following table.

The product result states that the graphic aspect scores $89.29 \%$ which means it is feasible and ready to be implemented. The material / content aspect received a score of $78.57 \%$ which means it is quite feasible and ready to be implemented. The presentation aspect gets a value of $83.33 \%$ which means it is feasible and implemented. The language and legibility aspects get a score of $100.00 \%$ which means it is feasible and implemented. 
The details of the results of the validation of BIPA teaching materials containing Batak culture by experts are as follows.

Table 2. The Result of Expert Assessments on Aspects of Appearance

\begin{tabular}{|c|c|c|c|c|c|}
\hline \multirow{3}{*}{ No } & \multirow{3}{*}{ Indicator } & \multicolumn{4}{|c|}{ Score } \\
\hline & & 1 & 2 & 3 & 4 \\
\hline & & $\mathbf{L}$ & $\mathbf{E}$ & $\mathbf{G}$ & VG \\
\hline 1 & Color composition & & & & $\sqrt{ }$ \\
\hline 2 & Cover image display & & & $\sqrt{ }$ & \\
\hline 3 & Writing on the cover & & & & $\sqrt{ }$ \\
\hline 4 & Use of font & & & & $\sqrt{ }$ \\
\hline 5 & Font type and size & & & & $\sqrt{ }$ \\
\hline 6 & Layout & & & $\sqrt{ }$ & \\
\hline 7 & Image & & & $\sqrt{ }$ & \\
\hline & Total & & & & \\
\hline & Total value & & & & \\
\hline & Percentage $\left(\mathrm{P}=\frac{\sum x}{\mathrm{~N}} \times 100 \%\right)$ & & & $\begin{array}{l}\% \\
\text { thy) }\end{array}$ & \\
\hline
\end{tabular}

Table 3. Result of Expert Assessment of Material / Content Aspects

\begin{tabular}{|c|c|c|c|c|c|}
\hline \multirow{3}{*}{ No } & \multirow{3}{*}{ Indicator } & \multicolumn{4}{|c|}{ Score } \\
\hline & & 1 & 2 & 3 & 4 \\
\hline & & $\mathbf{L}$ & $\mathbf{E}$ & $\mathbf{G}$ & VG \\
\hline 1 & $\begin{array}{l}\text { The conformity of content / material with } \\
\text { the BIPA A1 syllabus }\end{array}$ & & & & $\sqrt{ }$ \\
\hline 2 & $\begin{array}{l}\text { The suitability of the content / teaching } \\
\text { material with the learning objectives }\end{array}$ & & & $\sqrt{ }$ & \\
\hline 3 & $\begin{array}{l}\text { The suitability of content / material } \\
\text { selection with the needs of entry-level } \\
\text { foreign speakers }\end{array}$ & & & $\sqrt{ }$ & \\
\hline 4 & $\begin{array}{l}\text { Suitability of material with a predetermined } \\
\text { time allocation }\end{array}$ & & & $\sqrt{ }$ & \\
\hline 5 & $\begin{array}{l}\text { The accuracy of the material to support } \\
\text { foreign speakers in learning Indonesian }\end{array}$ & & & $\sqrt{ }$ & \\
\hline 6 & $\begin{array}{l}\text { Presentation of Batak culture content in } \\
\text { teaching materials }\end{array}$ & & & $\sqrt{ }$ & \\
\hline 7 & $\begin{array}{l}\text { The content of Batak culture on teaching } \\
\text { materials as a whole }\end{array}$ & & & $\sqrt{ }$ & \\
\hline & Total & & & & \\
\hline & Total Value & & & & \\
\hline & Percentage $\left(\mathrm{P}=\frac{\sum x}{\mathrm{~N}} \times 100 \%\right)$ & & Vol & & \\
\hline
\end{tabular}


Table 4. Result of Expert Assessment of Presentation Aspects

\begin{tabular}{|c|c|c|c|c|c|}
\hline \multirow{3}{*}{ No } & \multirow{3}{*}{ Indicator } & \multicolumn{4}{|c|}{ Score } \\
\hline & & 1 & 2 & 3 & 4 \\
\hline & & $\mathbf{L}$ & $\mathbf{E}$ & $\mathbf{G}$ & VG \\
\hline 1 & The accuracy of the material order & & & & $\sqrt{ }$ \\
\hline 2 & Continuity of material in teaching materials & & & & $\sqrt{ }$ \\
\hline 3 & $\begin{array}{l}\text { Suitability of the title and presentation of } \\
\text { material in each chapter }\end{array}$ & & & & $\sqrt{ }$ \\
\hline 4 & $\begin{array}{l}\text { The presentation of teaching materials can } \\
\text { motivate learning }\end{array}$ & & $\sqrt{ }$ & & \\
\hline 5 & $\begin{array}{l}\text { The presentation of the motivational section } \\
\text { can motivate foreign speakers }\end{array}$ & & $\sqrt{ }$ & & \\
\hline 6 & $\begin{array}{l}\text { The presentation of material on teaching } \\
\text { materials is complete and is able to meet the } \\
\text { needs of foreign speakers }\end{array}$ & & & & $\sqrt{ }$ \\
\hline & Total & & & & \\
\hline & Total Value & & & & \\
\hline & Percentage $\left(\mathrm{P}=\frac{\sum x}{\mathrm{~N}} \times 100 \%\right)$ & & & $\begin{array}{l}3 \% \\
\text { thy) }\end{array}$ & \\
\hline
\end{tabular}

Table 5. Results of Expert Assessments of Language and Readability Aspects

\begin{tabular}{|c|c|c|c|c|c|}
\hline \multirow{3}{*}{ No } & \multirow{3}{*}{ Indicator } & \multicolumn{4}{|c|}{ Score } \\
\hline & & 1 & 2 & 3 & 4 \\
\hline & & $\mathbf{L}$ & $\mathbf{E}$ & $\mathbf{G}$ & $\mathbf{V G}$ \\
\hline 1 & $\begin{array}{l}\text { Conformity with the rules of Indonesian } \\
\text { that are good and correct }\end{array}$ & & & & $\sqrt{ }$ \\
\hline 2 & Legibility & & & & $\sqrt{ }$ \\
\hline 3 & Clarity of information & & & & $\sqrt{ }$ \\
\hline 4 & $\begin{array}{l}\text { Use of the Indonesian language effectively } \\
\text { and efficiently }\end{array}$ & & & & $\sqrt{ }$ \\
\hline 5 & The rules of politeness in language & & & & $\sqrt{ }$ \\
\hline & Total & & & & \\
\hline & Total Value & & & & \\
\hline & Percentage $\left(\mathrm{P}=\frac{\sum x}{\mathrm{~N}} \times 100 \%\right)$ & & & $\begin{array}{l}0 \% \\
\text { thy) }\end{array}$ & \\
\hline
\end{tabular}

From the results of the feasibility validation of the four four aspects which include (1) the physical / physical dimensions, (2) the content / material dimensions, (3) the presentation dimensions, and (4) the language and readability dimensions, the percentage value of the feasibility value of BIPA teaching materials contains Batak culture is as follows: 
Table 6. Table of Recapitulation of the Results of Expert Assessment of BIPA Teaching Materials with Batak Culture

\begin{tabular}{|c|l|c|c|}
\hline \multirow{2}{*}{ No } & \multicolumn{1}{|c|}{ Aspect } & $\begin{array}{c}\text { Percentage of } \\
\text { Eligibility Value } \\
(\mathbf{\%})\end{array}$ & $\begin{array}{c}\text { Eligibility } \\
\text { Category }\end{array}$ \\
\hline 1 & Perwajahan/fisik & 89,29 & Worthy \\
\hline 2 & Isi/materi & 78,57 & Worthy Enough \\
\hline 3 & Penyajian & 83,33 & Worthy \\
\hline 4 & Bahasa dan keterbacaan & 100,00 & Worthy \\
\hline \multicolumn{2}{|c|}{ Total } & 351,19 & \multirow{2}{*}{ Wotal Value } \\
\hline \multicolumn{2}{|c|}{ Percentage $\left(\mathrm{P}=\frac{400,00}{\mathrm{~N}} \mathrm{~N}\right.$} & $\mathbf{8 7 , 8 0}$ & \\
\hline
\end{tabular}

Based on the table above, it can be concluded that BIPA teaching materials containing Batak culture are declared feasible to be implemented in BIPA learning activities.

\subsection{Revision}

Although overall the five components of teaching materials are feasible and ready to be implemented, revisions are made to the five components so that the teaching materials are getting better. Revisions are made to (1) book covers, (2) add information to illustration images, (3) writing errors, (4) increasingly varied exercises, and (5) providing written and audio attachments for aspects of listening skills.

\section{Conclusion}

The teaching material was developed under the name Indonesian for Foreign Speakers: Variety of Friends of Indonesia, which is equipped with a teaching guide as well as a recorded CD, practice questions, songs, and conversations. The teaching materials developed are feasible and ready to be implemented in terms of graphics, presentation, material / content, and language. However, revisions are still being made on the basis of verbal data obtained from experts, practitioners, and beginner BIPA students so that the teaching materials are getting better.

\section{References}

Alawiyah. 2014. Pengembangan Tes Keterampilan Menulis sebagai Upaya Penyiapan Alat Uji Kemahiran Berbahasa Indonesia bagi Penutur Asing. Bahasa: Antologi Pendidikan Bahasa dan Sastra Indonesia, Pembelajaran BIPA: No. 2, Desember 2014. Diambil dari http://ejournal.upi.edu/index.php/PSPBSI/article/view/499. (3 Agustus 2015).

Arikunto, Suharsimi. 2006. Prosedur Penelitian: Suatu Pendekatan Praktik. Jakarta: Rineka Cipta. Azizah, dkk. 2013. Pembelajaran Bahasa Indonesia bagi Penutur Asing (BIPA) Program CLS (Critical Language Scholarship) di Fakultas Sastra Universitas Negeri Malang Tahun 2012. Vokal: Universitas Negeri Malang, Vol.1, No.1 (2013). Diambil dari http://jurnal- online.um.ac.id/article/do/detail-article/1/11/1386. (3 Agustus 2015).

Bakker, J.W.M. 1984. Filsafat Kebudayaan: Sebuah Pengantar. Yogyakarta: Kanisius.

Bundhowi, M. 1999. Komponen Budaya dalam Pengajaran BIPA. IALF Bali. http://www.ialf.edu/bipa/july1999/komponenbudaya.html (29 September 2015). 
Daryanto. 2013. Menyusun Modul (Bahan Ajar untuk Persiapan Guru dalam Mengajar). Yogyakarta: Gava Media.

Depdiknas. 2006. Pedoman Memilih dan Menyusun Bahan Ajar. Jakarta: Depdiknas.

Depdiknas. 2008. Panduan Pengembangan Bahan Ajar. Jakarta: Depdiknas.

Fauziah, Shiva. 2014. Pengembangan Bahan Ajar Menyusun Teks Hasil Obsevasi Bermuatan Keberagaman Budaya Nusantara dengan Pendekatan Ilmiah untuk Peserta Didik SMP Kelas VII. Skripsi. Universitas Negeri Semarang.

Harian Kompas. 2013. BIPA, Tingkatkan Fungsi Bahasa Indonesia Menjadi Bahasa Internasional. Dalam http://edukasi.kompas.com/read/2013. Diunduh pada tanggal 9 Januari 2020 pukul 20.00 WIB.

Jarvis, Huw dan Marta Szymczyk. 2009. Student Views on Learning Grammar with Web and Book Based Materials. ELT Journal Volume 64/1 January 2010; doi:10.1093/elt/ccp006.

Koentjaraningrat. 2008. Kebudayaan, Mentalitas dan Pembangunan. Jakarta: Gramedia Pustaka Utama.

Majid, Abdul. 2008. Perencanaan Pembelajaran: Mengembangkan Standar Kompetensi Guru. Bandung: Remaja Rosda Karya.

Mustakim. 2003. Peranan Unsur Sosial Budaya dalam Pengajaran BIPA. Proceeding Konferensi Internasional Pengajaran Bahasa Indonesia bagi Penutur Asing IV. Denpasar: Indonesian Australia Language Foundation (IALF).

Nurlila, Layli, dan Eko Sri Israhayu. 2014. "BIPA Learning Material Development for Empowering Thailand Students' Writing Competence". International Journal for Educational Studies, 7(1) August 2014. Hal 59.

Nurqolila, Dian Tyas. 2010. Telaah Unsur-Unsur Budaya dalam Buku Teks BIPA "Living Indonesian". Skripsi. Jurusan Sastra Indonesia Universitas Negeri Malang.

Nurwicaksono, Bayu Dwi. 2013. "Folklor Lapindo sebagai Wawasan Geo- Culture dan GeoMythology Berbasis Kearifan Lokal dalam Pembelajaran Bahasa Indonesia Bagi Penutur Asing (BIPA)”. FPBS, Universitas Negeri Surabaya. bahasa \& sastra, Vol. 13, No.1, April 2013.

Siroj, Badrus. 2012. Pengembangan Model Integratif Bahan Ajar Bahasa Indonesia Ranah Sosial Budaya Berbasis ICT bagi Penutur Asing Tingkat Menengah. Tesis. Jurusan Sastra Indonesia Universitas Negeri Semarang.

Subektiningsih. 2007. Analisis Latihan-latihan dalam Buku Teks BIPA Lentera Indonesia. Skripsi. Universitas Malang.

Sugiono. 2008. Metode Penelitian Kuantitatif, Kualitatif, dan R\&D. Bandung: Alfabeta.

Sulistiyo. 2012. Model Pembelajaran Afiksasi melalui Media Cakram Digital (CD) Interaktif dalam Keterampilan Menulis untuk Pembelajar Bahasa Indonesia Bagi Penutur Asing (BIPA): Penelitian Eksperimen Subjek Tunggal terhadap Siswa Kelas VII SMP Mutiara Nasional International School Bandung Tahun Ajaran 2011/2012. Tesis. Universitas Pendidikan Indonesia.

Suyitno, Imam. 2007. "Pengembangan Bahan Ajar Bahasa Indonesia untuk Penutur Asing (BIPA) berdasarkan Hasil Analisis Kebutuhan Belajar". Wacana Vol.9 No.1, April (62 - 78).

Syahrin, A. (2018). Culture Repertoire in Expressive Written Language: Study of Hypothesis of Edward Sapir and Benyamin Lee Whorf. Budapest International Research and Critics in Linguistics and Education (BirLE) Journal. 1(1): 23-28

Tupan, Anneke Heritaningsih. 2007. Pengembangan Bahan Ajar BIPA Melalui Materi Otentik yang Bermuatan Budaya Indonesia. Seminar dan Lokakarya Internasional Pengajaran BIPA. Pusat Bahasa: Jakarta. 19 Juli 2007.

Widodo, S. Chomsin dan Jasmadi. 2008. Panduan Menyusun Bahan Ajar Berbasis Kompetensi. Jakarta: Elex Media Komputindo. 